\title{
Mossy Fiber Long-Term Potentiation Deficits in BACE1 Knock-Outs Can Be Rescued by Activation of $\alpha 7$ Nicotinic Acetylcholine Receptors
}

\author{
Hui Wang, ${ }^{1,2}$ Lihua Song, ${ }^{1}$ Angela Lee, ${ }^{1}$ Fiona Laird, ${ }^{3,4}$ Philip C. Wong, ${ }^{3,4}$ and Hey-Kyoung Lee ${ }^{1,2}$ \\ ${ }^{1}$ Department of Biology, College of Chemical and Life Sciences, and ${ }^{2}$ Neuroscience and Cognitive Science Program, University of Maryland, College Park, \\ Maryland 20742, and Departments of ${ }^{3}$ Pathology and ${ }^{4}$ Neuroscience, Johns Hopkins University School of Medicine, Baltimore, Maryland 21205
}

\begin{abstract}
$\beta$-Site amyloid precursor protein-cleaving enzyme 1 (BACE1) - the neuronal $\beta$-secretase responsible for producing $\beta$-amyloid (A $\beta$ ) peptides - emerged as one of the key therapeutic targets of Alzheimer's disease (AD). Although complete ablation of the BACE1 gene prevents $\mathrm{A} \beta$ formation, we reported that BACE1 knock-out mice display severe presynaptic deficits at mossy fiber (MF)-to-CA3 synapses in the hippocampus, a major locus of BACE1 expression. We also found that the deficits are likely due to abnormal presynaptic Ca ${ }^{2+}$ regulation. Cholinergic system has been implicated in $\mathrm{AD}$, in some cases involving $\mathrm{Ca}^{2+}$-permeable $\alpha 7$-nicotinic acetylcholine receptors (nAChRs). Here we report that brief application of nicotine, via $\alpha 7$-nAChRs, can restore MFlong-term potentiation in BACE1 knock-outs. Our data suggest that activating $\alpha 7$-nAChRs can recover the presynaptic deficits in BACE1 knock-outs.
\end{abstract}

\section{Introduction}

Alzheimer's disease $(\mathrm{AD})$ is the most prevalent form of senile dementia with limited treatment options (Vassar et al., 2009). A current hypothesis of AD states that overexpression of amyloid- $\beta$ $(\mathrm{A} \beta)$ peptide initiates a cascade of events leading to its pathology (Walsh and Selkoe, 2007). $\beta$-Site amyloid precursor proteincleaving enzyme 1 (BACE1), the neuronal $\beta$-secretase, is the first enzyme involved in the sequential cleavage of amyloid precursor proteins (APPs) to produce A $\beta$ (Vassar et al., 2009). High levels of BACE1 are correlated with an increase in $A \beta$ in sporadic $A D$ (Hébert et al., 2008; O'Connor et al., 2008). Knocking out BACE1 abolishes A $\beta$ peptide production (Cai et al., 2001), prevents amyloid plaque deposition, and rescues memory deficits in APP transgenic lines (Luo et al., 2003; Ohno et al., 2004). These observations encourage the development of BACE1 inhibition strategies for $\mathrm{AD}$ treatment. However, studies revealed that BACE1 knock-outs (KOs) display behavior deficits (Harrison et al., 2003; Laird et al., 2005; Savonenko et al., 2008) and specific synaptic dysfunctions in the CA1 of hippocampus (Laird et al., 2005). Moreover, at the MF-to-CA3 synapses, where high levels of BACE1 are expressed (Laird et al., 2005), BACE1 KOs display severe presynaptic dysfunctions (Wang et al., 2008). The deficits include a reduction in presynaptic release and an absence of mossy fiber long-term potentiation (mfLTP), which are due to

Received March 2, 2010; revised Aug. 17, 2010; accepted Aug. 19, 2010.

This work was supported by a grant from the National Institutes of Health (P01-NS047308) to P.C.W. and H.-K.L., the Graduate Student Summer Research Fellowship [University of Maryland (UMD)] and the Robert and Florence Deutsch Graduate Award (UMD) to H.W., and the Howard Hughes Medical Institute Undergraduate Research Fellowship to A.L.

Correspondence should be addressed to Hey-Kyoung Lee, Department of Biology, University of Maryland, 1210 Bio-Psych Building, College Park, MD 20742. E-mail: hlee21@umd.edu.

DOI:10.1523/JNEUROSCI.1070-10.2010

Copyright $\odot 2010$ the authors $\quad 0270-6474 / 10 / 3013808-06 \$ 15.00 / 0$ abnormal presynaptic $\mathrm{Ca}^{2+}$ signaling (Wang et al., 2008). These studies caution against the use of BACE1 inhibitors as a practical treatment for $\mathrm{AD}$.

Cholinergic system modulates neurotransmitter release from glutamatergic and GABAergic terminals via the action of nicotinic acetylcholine receptors (nAChRs) (Gray et al., 1996; Radcliffe et al., 1999; Giocomo and Hasselmo, 2005; Jiang and Role, 2008; Bancila et al., 2009). Among them, $\alpha 7-n A C h R$ is a $\mathrm{Ca}^{2+}$-permeable homopentameric ion channel highly expressed in the hippocampus and cerebral cortex (Séguéla et al., 1993). Several studies have linked $\alpha 7$-nAChR with neurodegenerative disorders, including AD (Perry et al., 2000). We present data that activating $\alpha 7-\mathrm{nAChRs}$, by nicotine (Nic) or a specific agonist, PNU282987, can restore presynaptic function and mfLTP in BACE1 KOs via recruiting calcium-induced calcium release (CICR).

\section{Materials and Methods}

Animals. All mice used (BACE1 $+/+$ and $-/-$ ) were derived from heterozygous breeders (+/-) as described previously (Laird et al., 2005). The Institutional Animal Care and Use Committees of both University of Maryland and Johns Hopkins University approved all procedures involving animals.

Electrophysiological recordings. Hippocampal slices (400 $\mu \mathrm{m}$ thick) were prepared from adult (3-6 months old) male BACE1 KOs and wild types (WTs) as previously described (Wang et al., 2008). Briefly, hippocampi were sliced in ice-cold dissection buffer (in mM: 212.7 sucrose, $2.6 \mathrm{KCl}, 1.23 \mathrm{NaH}_{2} \mathrm{PO}_{4}, 26 \mathrm{NaHCO}_{3}, 10$ dextrose, $3 \mathrm{MgCl}_{2}$, and $1 \mathrm{CaCl}_{2}$; $\left.5 \% \mathrm{CO}_{2} / 95 \% \mathrm{O}_{2}\right)$. Recordings were done in a submersion-type chamber perfused with artificial CSF (ACSF, in mM: $124 \mathrm{NaCl}, 5 \mathrm{KCl}, 1.25$ $\mathrm{NaH}_{2} \mathrm{PO}_{4}, 26 \mathrm{NaHCO}_{3}, 10$ dextrose, $1.5 \mathrm{MgCl}_{2}$, and $2.5 \mathrm{CaCl}_{2} ; 5 \% \mathrm{CO}_{2} /$ $\left.95 \% \mathrm{O}_{2}, 29.5-30.5^{\circ} \mathrm{C}, 2 \mathrm{ml} / \mathrm{min}\right)$. Synaptic responses were evoked through glass bipolar stimulating electrodes placed in the dentate granule cell layer to activate MFs with pulse duration of $0.2 \mathrm{~ms}$ (at $0.067 \mathrm{~Hz}$ ), and recorded extracellularly in the stratum lucidum of CA3. Paired-pulse 

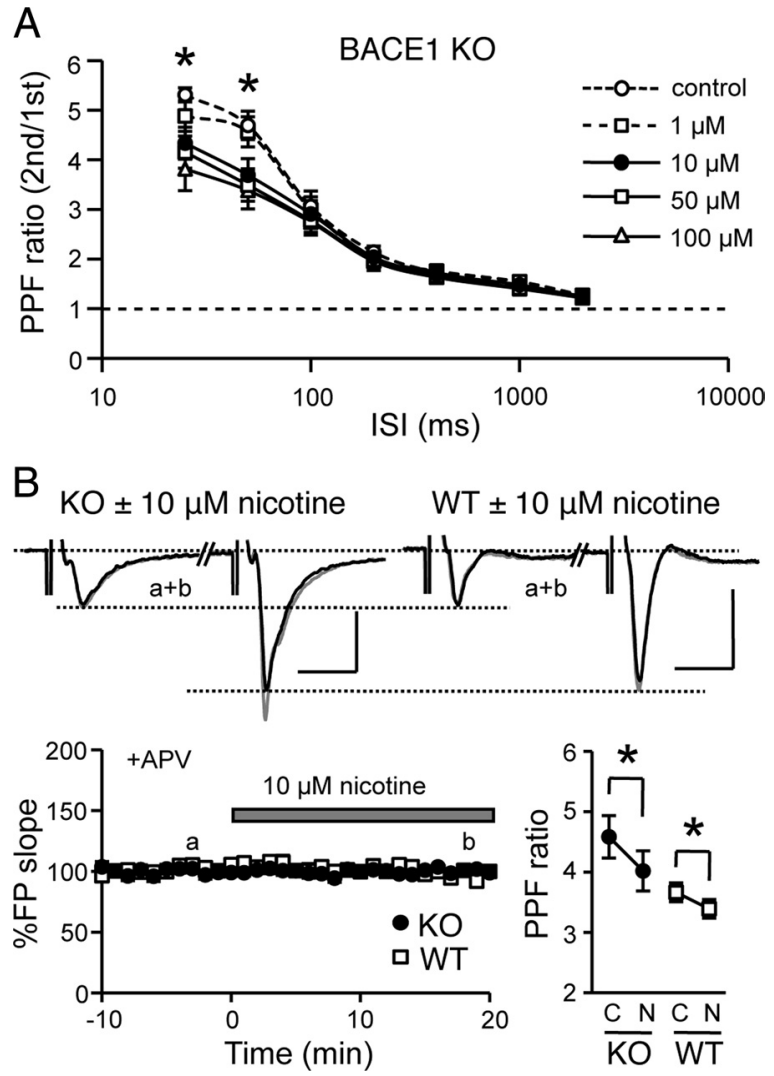

Figure 1. Nicotine recovers deficits in PPF at MF synapses in BACE1 KOs. $\boldsymbol{A}$, Nicotine reduced PPF ratio in a dose-dependent manner, which was significant at 25 and 50 ms ISIs. *ANOVA, $p<0.05$; Fisher's PLSD, $p<0.05$ between control and 10, 50, $100 \mu \mathrm{m}$ nicotine groups. $\boldsymbol{B}$, Nicotine $(10 \mu \mathrm{m})$ significantly decreased PPF ratio in both genotypes, but did not influence basal synaptic transmission. Top, Representative FP traces of paired-pulse stimulation (50 ms ISI) before (thin traces) and after (thick traces) nicotine. Calibration: K0, $1 \mathrm{mV}$; WT, $0.5 \mathrm{mV}, 10$ ms. Bottom left, No change in basal synaptic strength with nicotine (KO, black circles; WT, open squares). Bottom right, Comparison of PPF ratio (50 ms ISI) before (C) and after (N) nicotine application. *Paired $t$ test, $p<0.001$.

facilitation (PPF) was measured at 25, 50, 100, 200, 400, 1000, and 2000 ms interstimulus intervals (ISIs). To induce mfLTP, three trains of 100 $\mathrm{Hz}$ ( $1 \mathrm{~s}$ ) stimuli were given at $20 \mathrm{~s}$ intervals. We used $\alpha 7-\mathrm{nAChR}$ agonists (-)-nicotine (Sigma-Aldrich) and PNU282987 (Tocris Bioscience), and an antagonist $\alpha$-bungarotoxin (Tocris Bioscience). To block intracellular $\mathrm{Ca}^{2+}$ release, ruthenium red (Tocris Bioscience) or ryanodine (Tocris Bioscience) was applied. All experiments were done in the presence of $100 \mu \mathrm{M}$ D,L-2-amino-5-phosphonovaleric acid (D,L-APV) (SigmaAldrich) to isolate the presynaptic NMDAR-independent mfLTP (Nicoll and Schmitz, 2005). At the end of each experiment, $1 \mu \mathrm{M}$ $\left(2 S, 2^{\prime} R, 3^{\prime} R\right)$-2-(2', $3^{\prime}$-dicarboxycyclopropyl)glycine (DCG-IV) (Tocris Bioscience) was added, and responses blocked by $\geq 80 \%$ were taken to be MF inputs. Field potential slopes were measured, and data are expressed as mean \pm SEM.

\section{Results}

\section{Nicotine restores presynaptic function at MF synapses in BACE1 KOs}

We first examined the effect of nicotine on the presynaptic function of MFs in BACE1 KOs by measuring PPF. The results showed that nicotine decreased PPF ratio in a dose-dependent manner at 25 and $50 \mathrm{~ms}$ ISIs in KOs $(n=7$ slices $/ 3$ mice; ANOVA: $p<0.05$ ) (Fig. $1 A$ ), and $10 \mu \mathrm{M}$ was the lowest concentration that significantly decreased PPF ratio in both genotypes $(\mathrm{KO}:$ control $=4.81 \pm 0.16$, nicotine $=4.05 \pm 0.22, n=15$ slices $/ 10$ mice, paired $t$ test: $p<0.001$; WT: control $=3.77 \pm$
0.43 , nicotine $=3.50 \pm 0.40, n=10$ slices $/ 9$ mice, paired $t$ test: $p<0.001$ ) (Fig. $1 B$ ). We previously showed that BACE1 KOs display a significant increase in PPF ratio at MF synapses indicating a reduction in presynaptic release (Wang et al., 2008). Nicotine at $10 \mu \mathrm{M}$ concentration decreased the PPF ratio of KOs to a similar level of WTs ( $t$ test: $p=0.57$ ) without affecting synaptic transmission in either genotype (KO: $100 \pm 1 \%$ of baseline at 20 min after nicotine, $n=15$ slices $/ 10$ mice; paired $t$ test: $p=0.97$; WT: $99 \pm 1 \%, n=10$ slices $/ 9$ mice; paired $t$ test: $p=0.54$ ) (Fig. $1 B$ ). These results suggest that $10 \mu \mathrm{M}$ nicotine reverses PPF deficits in BACE1 KOs without affecting synaptic strength. Therefore, $10 \mu \mathrm{M}$ nicotine was used in subsequent experiments.

\section{Nicotine rescues mfLTP in BACE1 KOs without affecting mfLTP in WTs}

Consistent with our previous results, KOs lacked mfLTP under control conditions, but $10 \mu \mathrm{M}$ nicotine applied during the whole duration of the experiment restored mfLTP [control: $95 \pm 4 \%$ at $1 \mathrm{~h}$ after high-frequency stimulation (HFS), $n=6$ slices $/ 4$ mice; nicotine: $133 \pm 7 \%, n=8$ slices $/ 7$ mice; $t$ test: $p<0.001$ ] (Fig. $2 A)$. Nicotine-induced rescue of mfLTP was accompanied by a significant decrease in PPF ratio (50 ms ISI; baseline: $4.36 \pm 0.26$, $1 \mathrm{~h}$ after HFS: $3.01 \pm 0.27$, paired $t$ test: $p<0.001$ ) (Fig. $2 \mathrm{~A}$, inset), suggesting presynaptic expression. Interestingly, $10 \mu \mathrm{M}$ nicotine did not alter the magnitude of mfLTP in WTs (control: $148 \pm 3 \%$ at $1 \mathrm{~h}$ after HFS, $n=5$ slices/ 3 mice; nicotine: $144 \pm$ $6 \%, n=7$ slices $/ 6$ mice; $t$ test: $p=0.52$ ) (Fig. $2 B$ ).

To investigate whether nicotine affects the induction mechanisms of mfLTP, we transiently applied nicotine for $10 \mathrm{~min}$ before and during the HFS. KOs displayed significant mfLTP, which was similar in magnitude with that evoked in WTs $(\mathrm{KO}=$ $147 \pm 2 \%$ at $1 \mathrm{~h}$ after HFS, $n=8$ slices $/ 5$ mice, paired $t$ test: $p<$ 0.001; WT: $157 \pm 8 \%, n=8$ slices $/ 5$ mice, paired $t$ test: $p<0.001$ ) (Fig. $2 C, D$ ). Furthermore, mfLTP was accompanied by a significant decrease in PPF ratio (50 ms ISI) in both genotypes (WT: baseline $=3.66 \pm 0.16,1 \mathrm{~h}$ after HFS $=2.55 \pm 0.21$, paired $t$ test: $p<0.001 ; \mathrm{KO}$ : baseline $=4.59 \pm 0.35,1 \mathrm{~h}$ after HFS $=2.95 \pm$ 0.33 , paired $t$ test: $p<0.001$ ) (Fig. $2 C, D$, insets), consistent with an increase in presynaptic release. These results demonstrate that nicotine specifically rescues the induction mechanisms of mfLTP in BACE1 KOs.

\section{Nicotine-induced rescue of $\mathrm{mfLTP}$ in BACE1 KOs is mediated by $\alpha 7-\mathrm{nAChRs}$}

We showed that presynaptic dysfunction of MF synapses in $\mathrm{BACE} 1 \mathrm{KOs}$ is at the level of $\mathrm{Ca}^{2+}$ regulation (Wang et al., 2008). To determine whether nicotine acts via the $\mathrm{Ca}^{2+}$-permeable $\alpha 7$ nAChRs, we used a specific agonist, PNU282987 (Bodnar et al., 2005). A brief application of PNU282987 (500 nM, $10 \mathrm{~min}$ ) before and during HFS recovered mfLTP in KOs ( $1 \mathrm{~h}$ after HFS: $167 \pm$ 19\%, $n=8$ slices $/ 5$ mice; paired $t$ test: $p<0.05$ ) (Fig. $3 A$ ) for up to $2 \mathrm{~h}$ (supplemental Fig. 1, available at www.jneurosci.org as supplemental material). Furthermore, PPF ratio decreased significantly after PNU282987 application and further by LTP induction (baseline: $6.29 \pm 0.77,+$ PNU282987: $5.81 \pm 0.76,1 \mathrm{~h}$ after HFS: $4.80 \pm 0.69$ ) (Fig. 3A, inset). PNU282987 alone did not produce changes in synaptic strength ( $1 \mathrm{~h}$ after PNU282987: $105 \pm 4 \%, n=4$ slices $/ 2$ mice; paired $t$ test: $p=0.30)$ (Fig. $3 A$ ).

To further test whether nicotine-induced rescue of mfLTP was mediated by $\alpha 7$-nAChRs, we applied $100 \mathrm{~nm} \alpha$-bungarotoxin $(\alpha \mathrm{BTX})$, a selective antagonist. $\alpha \mathrm{BTX}$ abolished the effect of nicotine on mfLTP ( $1 \mathrm{~h}$ after HFS: $105 \pm 4 \%, n=10$ slices $/ 6$ 
mice; paired $t$ test: $p>0.05)$ (Fig. $3 B$ ) and PPF ratio $(\alpha \mathrm{BTX}: 5.22 \pm 0.65$, $\alpha$ BTX + nicotine: $5.17 \pm 0.65,1 \mathrm{~h}$ after HFS: $5.19 \pm 0.73$ ) (Fig. $3 B$, inset) in KOs. Application of $\alpha \mathrm{BTX}$ and nicotine in the absence of HFS did not alter synaptic transmission ( $1 \mathrm{~h}$ after $\alpha \mathrm{BTX}+\mathrm{Nic}: 100 \pm$ $1 \%, n=4$ slices $/ 2$ mice; paired $t$ test: $p=$ 0.86 ) (Fig. $3 B$ ). These results suggest that nicotine-induced rescue of presynaptic deficits in BACE1 KOs is mediated by $\alpha 7$-nAChRs.

Finally, we tested whether $\alpha 7$-nAChRs are required for mfLTP in WTs. A brief application of $\alpha$ BTX (10 $\mathrm{min}$ ) before and during HFS failed to block mfLTP in WTs ( 1 h after HFS: $148 \pm 6 \%, n=9$ slices $/ 7$ mice; paired $t$ test: $p<0.001$ ) (Fig. $3 C$ ). This indicates that activation of $\alpha 7$ nAChRs is not necessary for mfLTP induction in WTs, hence the rescue of mfLTP in KOs by $\alpha 7-n A C h R$ activation is probably via recruitment of an alternative pathway not normally used in WTs.

\section{CICR is involved in nicotine-induced rescue of mfLTP in BACE1 KOs}

Activation of $\alpha 7$-nAChRs enhances CICR from ryanodine-sensitive $\mathrm{Ca}^{2+}$ stores (Sharma and Vijayaraghavan, 2003; Sharma et al., 2008). To investigate whether CICR is also involved in nicotine-induced rescue of $\mathrm{MfLTP}$ in KOs, we used $20 \mu \mathrm{M}$ ruthenium red (RR) or $100 \mu \mathrm{M}$ ryanodine (Ryan), which are blockers of ryanodine-sensitive stores. Both drugs completely abolished nicotineinduced recovery of PPF ratio [RR: $5.00 \pm 0.69, \mathrm{RR}+\mathrm{Nic}: 4.97 \pm$ 0.70, $1 \mathrm{~h}$ after HFS: $4.62 \pm 0.74$ (Fig. $4 A$, inset); Ryan: $5.01 \pm$ 0.20, Ryan+Nic: $5.03 \pm 0.23,1 \mathrm{~h}$ after HFS: $4.93 \pm 0.25]$ and mfLTP $(1 \mathrm{~h}$ after RR + Nic: $91 \pm 5 \%, n=9$ slices $/ 5$ mice; paired $t$ test: $p=0.18$; 1 h after Ryan +Nic: $100 \pm 2 \%, n=6$ slices $/ 3$ mice; paired $t$ test: $p=0.66$ ) (Fig. $4 A$ ) in KOs without influencing basal synaptic transmission. mfLTP was present in WTs treated with RR ( 1 h after HFS: $124 \pm 5 \%, n=9$ slices $/ 5$ mice; paired $t$ test: $p<0.01$ ) (Fig. $4 B$ ), but was significantly less than that in control WTs $(t$ test: $p<0.01$ ), suggesting that CICRs are only partially involved.

\section{Discussion}

We found that nicotine restores PPF and LTP at MF-to-CA3 synapses in BACE1 KOs. The nicotine effect was mimicked by $\alpha 7$-nAChR-specific agonist PNU282987, and blocked by $\alpha 7$ $\mathrm{nAChR}$ antagonist $\alpha \mathrm{BTX}$. We have evidence that nicotine acts via recruiting CICR. These results suggest nicotine and $\alpha 7-\mathrm{nAChR}$ agonists as potential pharmacological means to circumvent the presynaptic deficits caused by BACE1 inhibition.

mfLTP is presynaptically expressed, requiring an increase in presynaptic $\mathrm{Ca}^{2+}$ and a subsequent activation of cAMP-PKA signaling pathway (Nicoll and Schmitz, 2005). We previously demonstrated that presynaptic dysfunction seen in BACE1 KOs is at the level of $\mathrm{Ca}^{2+}$ regulation, but the downstream PKA signaling is
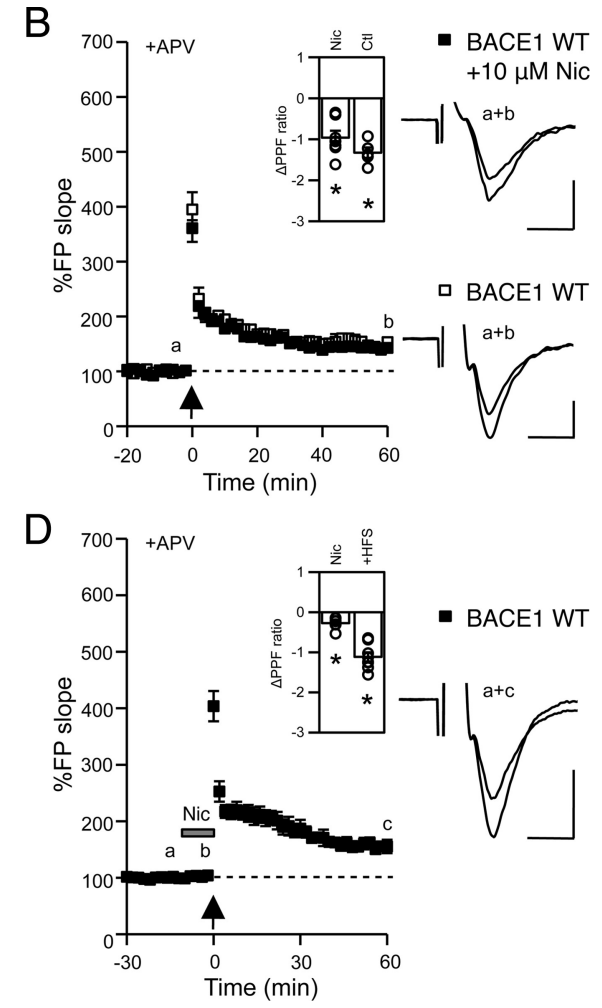

Figure 2. Nicotine rescues mfLTP in BACE1 KOs without effects in WTs. $A$, KO slices treated with $10 \mu \mathrm{m}$ nicotine (black circles) showed significant mfLTP compared to control slices without nicotine (open circles). $\boldsymbol{B}$, The magnitude of mfLTP in WT slices (black squares) was similar to that of control WT slices (open squares). C, Transient application of (PPF ratio at time a)] for control (Ctl) and Nic; $C, D, \Delta$ PPF ratio with nicotine application [(PPF ratio b) - (PPF ratio at time a)] and with HFS [(PPF ratio at time c) - (PPF ratio at time a)]. Bars, Average \pm SEM. Open circles, Individual data points. *Paired $t$ test, $p<0.001$. Arrow, HFS $(100 \mathrm{~Hz}, 1 \mathrm{~s} \times 3)$. Right panels, Superimposed FP traces taken at times indicated in the left panels. Calibration: $0.5 \mathrm{mV}, 5 \mathrm{~ms}$.

intact (Wang et al., 2008). These results predict that restoring presynaptic $\mathrm{Ca}^{2+}$ signaling should recover mfLTP in BACE1 KOs. Presynaptic $\alpha 7$-nAChR elevates the intracellular concentration of free $\mathrm{Ca}^{2+}$ (Vijayaraghavan et al., 1992) and enhances glutamate release at MF terminals (Sharma and Vijayaraghavan, 2003; Sharma et al., 2008; Bancila et al., 2009). The nicotineinduced rescue of PPF and mfLTP without much effect on basal synaptic transmission is likely via the recruitment of CICR, which is known to preferentially amplify use-dependent release (Shimizu et al., 2008). Short-term presynaptic plasticity, including PPF, does not depend on CICR at MF terminals (Carter et al., 2002). Consistent with this, inhibiting CICRs in WTs did not alter PPF ratio, but reduced mfLTP magnitude, which suggests that HFS recruits CICR. In the case of KOs, it is clear that the CICR triggered by $\alpha 7-\mathrm{nAChR}$ activation is needed to rescue mfLTP. Although we cannot rule out the possible involvement of $\alpha 7$-nAChRs on interneurons, the detection of $\alpha 7$-nAChR immunoreactivity in the MF input region (supplemental Fig. 2, available at www.jneurosci.org as supplemental material) provides a substrate for $\alpha 7-\mathrm{nAChR}$ agonists to act on MF terminals. This is further corroborated by a recent electron microscopy study, which localized $\alpha 7-n A C h R s$ on MF terminals (Bancila et al., 2009). Interestingly, the $\alpha 7$ nAChRs were present away from the active zone, suggesting an indirect regulation of presynaptic release.

It is known that $\alpha 7$-nAChRs can rapidly desensitize upon agonist binding in a dose-dependent manner (Peng et al., 1994). 


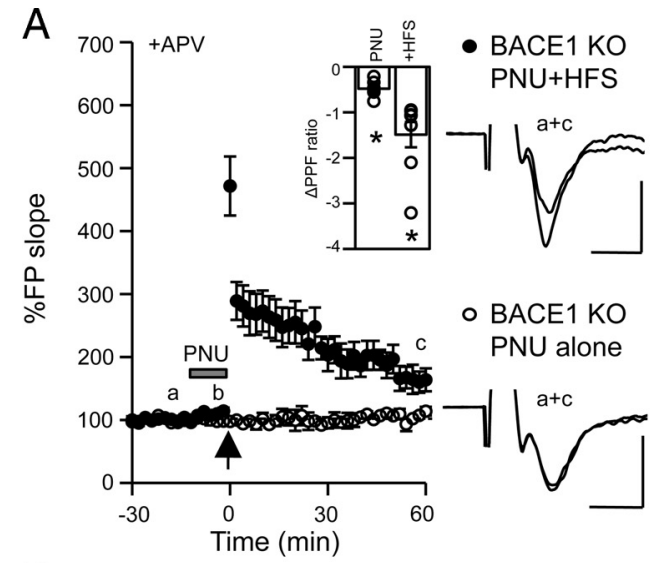

B
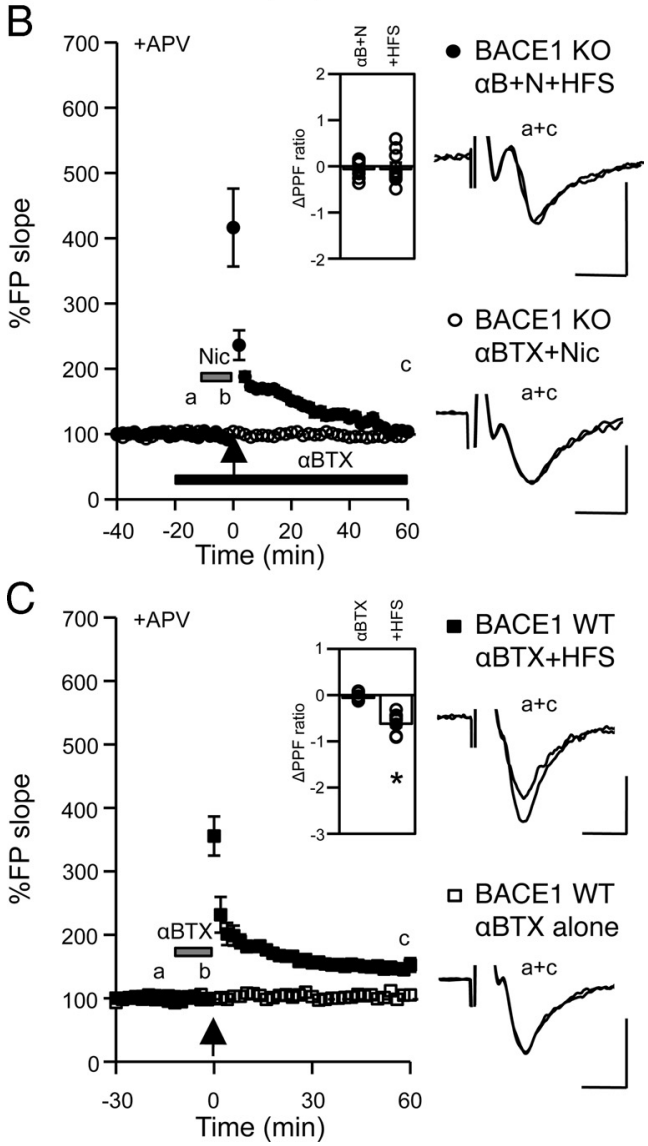

Figure 3. Nicotine-induced rescue of $\mathrm{mLLTP}$ in BACE1 $\mathrm{KO}$ is mediated by $\alpha 7$-nAChRs. $\boldsymbol{A}$, Transient bath application of PNU282987 (PNU: $500 \mathrm{~nm}, 10 \mathrm{~min}$; gray bar) rescued mfLTP in KOs (black circles). PNU282987 alone did not alter synaptic transmission (open circles). Inset, $\triangle$ PPF ratio in KO PNU + HFS experiments. $\triangle$ PPF ratio with PNU282987 application [(PPF atb) - (PPF at a)]; $\Delta$ PPF ratio with HFS [(PPF at c) - (PPF at a)], ${ }^{*}$ paired $t$ test: $p<0.01$. $B$, Application of $\alpha B T X$ (100 nm, black bar) blocked nicotine-induced rescue of mfLTP in KOs (black circles). Application of $\alpha$ BTX and nicotine without HFS did not influence basal synaptic transmission (open circles). Inset, $\triangle \mathrm{PPF}$ ratio in $\mathrm{KO} \alpha \mathrm{BTX}+\mathrm{Nic}+\mathrm{HFS}$ experiments. $\triangle \mathrm{PPF}$ ratio with nicotine application in the presence of $\alpha \mathrm{BTX}$ [(PPF at $\mathrm{b})-$ (PPF at a)]; $\triangle$ PPF ratio with HFS [(PPF at c) (PPF at a)]. C, mfLTP in wild type is not blocked by $\alpha$ BTX. $\alpha$ BTX alone ( $100 \mathrm{~nm}, 10 \mathrm{~min}$; gray bar) did not affect synaptic transmission (open squares). Black squares, $\alpha \mathrm{BTX}+\mathrm{HFS}$. Inset (for $\alpha \mathrm{BTX}+\mathrm{HFS}$ experiments), $\triangle \mathrm{PPF}$ ratio with $\alpha \mathrm{BTX}$ [(PPF at b) - (PPF at a)]; $\triangle \mathrm{PPF}$ ratio with HFS $[(P P F$ at $c)-($ PPF at a) $)$; *Paired $t$ test, $p<0.001$. Right, $F P$ traces. Calibration: $0.5 \mathrm{mV}, 5 \mathrm{~ms}$.

Because nicotine-induced rescue of mfLTP was blocked by $\alpha \mathrm{BTX}$, we suspect residual $\alpha 7-\mathrm{nAChR}$ activity even with the prolonged application of nicotine used in our study. Interestingly, the increase in glutamate release at MF terminals with $\alpha 7-\mathrm{nAChR}$
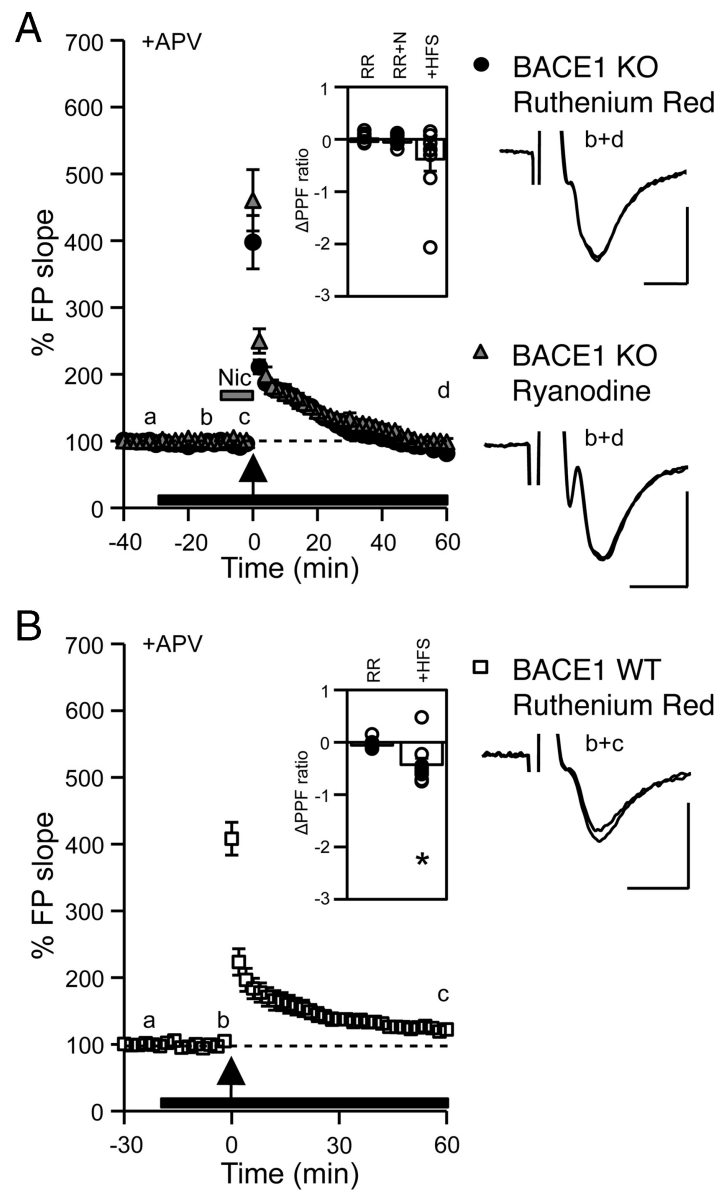

Figure 4. Nicotine-induced rescue of mfLTP in BACE1 KOs requires CICR. A, Application (black bar) of RR $(20 \mu \mathrm{m})$ or Ryan $(100 \mu \mathrm{m})$ abolished nicotine-induced rescue of mfLTP in KOs (RR: black circles, Ryan: gray triangles). Inset, $\triangle$ PPF ratio of RR application [(PPF at b) - (PPF at a)], + nicotine [(PPF at $c)-($ PPF at b) $]$, and + HFS [(PPF at d) - (PPF at b)]. B, RR (20 $\mu$ m; black bar) reduced mfLTP in WTs (open squares). Inset, $\triangle P P F$ ratio of RR application [(PPF at b) (PPF at a)] and + HFS [(PPF at $c)-($ PPF at b)]. *Paired $t$ test, $p<0.01$. Right, FP traces. Calibration: $0.5 \mathrm{mV}, 5 \mathrm{~ms}$.

activation is rather slow and involves presynaptic $\mathrm{Ca}^{2+}$ increase via CICR from internal stores (Sharma and Vijayaraghavan, 2003; Sharma et al., 2008). In synaptosomes isolated from the prefrontal cortex, $\alpha 7$-nAChR agonist-induced glutamate release is dependent on CICR and a downstream activation of extracellular signal-regulated kinase (ERK) signaling (Dickinson et al., 2008). These results suggest that presynaptic signaling of $\alpha 7$ nAChRs leading to glutamate release may outlast the initial activation of the receptor.

The regulation of $\alpha 7$-nAChRs has been implicated in the pathology of $\mathrm{AD}$. There are studies reporting high-affinity binding between $\mathrm{A} \beta 42$ and $\alpha 7$-nAChRs (Wang et al., 2000a,b), which either inhibit (Guan et al., 2001; Liu et al., 2001; Pettit et al., 2001) or activate (Dineley et al., 2001) $\alpha 7$-nAChR signaling. It is possible that $\mathrm{A} \beta 42$ may facilitate $\alpha 7-\mathrm{nAChRs}$ at low concentration, but may inhibit nAChRs when the burden of $\mathrm{A} \beta$ peptides increases (Dineley et al., 2001; Dougherty et al., 2003). The concentration-dependent dual role of $\mathrm{A} \beta 42$ is evident in a study showing that picomolar range of $\mathrm{A} \beta 42$ facilitates, but nanomolar range abolishes, LTP in CA1 and learning via its action on $\alpha 7$ nAChRs (Puzzo et al., 2008). It is unlikely that endogenous $A \beta 42$ acts in this manner to influence mfLTP, because blocking $\alpha 7$ nAChRs with $\alpha$-BTX did not affect mfLTP in WTs. This result 
indirectly argues that the lack of mfLTP in BACE1 KOs may not be a strict consequence of lacking $A \beta$. Interestingly, BACE1 has been found to regulate neuregulin-1 (NRG1) cleavage (Hu et al., 2006; Willem et al., 2006), and indeed this process is affected in BACE1 KOs (Savonenko et al., 2008). NRG1 is critically involved in maintaining surface expression of presynaptic $\alpha 7$-nAChRs (Hancock et al., 2008; Zhong et al., 2008). However, in isolated CA3 slices, we did not see a change in the total or cell surface levels of $\alpha 7$-nAChRs and NRG1 in the KOs (supplemental Fig. 3, available at www.jneurosci.org as supplemental material). Furthermore, our ability to rescue mfLTP in KOs with $\alpha 7$-nAChR agonists suggests sufficient presence of functional $\alpha 7$-nAChRs.

Several potential methods are being developed to overcome dysfunctions caused by complete BACE1 inhibition, such as partial BACE1 inhibition (Vassar et al., 2009). While our results might reflect a developmental loss of BACE1, they suggest that combining $\alpha 7$-nAChR agonists with BACE1 inhibitors may be another alternative.

\section{References}

Bancila V, Cordeiro JM, Bloc A, Dunant Y (2009) Nicotine-induced and depolarisation-induced glutamate release from hippocampus mossy fibre synaptosomes: two distinct mechanisms. J Neurochem 110:570-580.

Bodnar AL, Cortes-Burgos LA, Cook KK, Dinh DM, Groppi VE, Hajos M, Higdon NR, Hoffmann WE, Hurst RS, Myers JK, Rogers BN, Wall TM, Wolfe ML, Wong E (2005) Discovery and structure-activity relationship of quinuclidine benzamides as agonists of alpha7 nicotinic acetylcholine receptors. J Med Chem 48:905-908.

Cai H, Wang Y, McCarthy D, Wen H, Borchelt DR, Price DL, Wong PC (2001) BACE1 is the major beta-secretase for generation of Abeta peptides by neurons. Nat Neurosci 4:233-234.

Carter AG, Vogt KE, Foster KA, Regehr WG (2002) Assessing the role of calcium-induced calcium release in short-term presynaptic plasticity at excitatory central synapses. J Neurosci 22:21-28.

Dickinson JA, Kew JN, Wonnacott S (2008) Presynaptic alpha 7- and beta 2-containing nicotinic acetylcholine receptors modulate excitatory amino acid release from rat prefrontal cortex nerve terminals via distinct cellular mechanisms. Mol Pharmacol 74:348-359.

Dineley KT, Westerman M, Bui D, Bell K, Ashe KH, Sweatt JD (2001) $\beta$-Amyloid activates the mitogen-activated protein kinase cascade via hippocampal $\alpha 7$ nicotinic acetylcholine receptors: in vitro and in vivo mechanisms related to Alzheimer's disease. J Neurosci 21:4125-4133.

Dougherty JJ, Wu J, Nichols RA (2003) $\beta$-Amyloid regulation of presynaptic nicotinic receptors in rat hippocampus and neocortex. J Neurosci 23:6740-6747.

Giocomo LM, Hasselmo ME (2005) Nicotinic modulation of glutamatergic synaptic transmission in region CA3 of the hippocampus. Eur J Neurosci 22:1349-1356.

Gray R, Rajan AS, Radcliffe KA, Yakehiro M, Dani JA (1996) Hippocampal synaptic transmission enhanced by low concentrations of nicotine. Nature 383:713-716.

Guan ZZ, Miao H, Tian JY, Unger C, Nordberg A, Zhang X (2001) Suppressed expression of nicotinic acetylcholine receptors by nanomolar beta-amyloid peptides in PC12 cells. J Neural Transm 108:1417-1433.

Hancock ML, Canetta SE, Role LW, Talmage DA (2008) Presynaptic type III neuregulin1-ErbB signaling targets alpha7 nicotinic acetylcholine receptors to axons. J Gen Physiol 131:i4.

Harrison SM, Harper AJ, Hawkins J, Duddy G, Grau E, Pugh PL, Winter PH, Shilliam CS, Hughes ZA, Dawson LA, Gonzalez MI, Upton N, Pangalos MN, Dingwall C (2003) BACE1 (beta-secretase) transgenic and knockout mice: identification of neurochemical deficits and behavioral changes. Mol Cell Neurosci 24:646-655.

Hébert SS, Horré K, Nicolaï L, Papadopoulou AS, Mandemakers W, Silahtaroglu AN, Kauppinen S, Delacourte A, De Strooper B (2008) Loss of microRNA cluster miR-29a/b-1 in sporadic Alzheimer's disease correlates with increased BACE1/beta-secretase expression. Proc Natl Acad Sci U S A 105:6415-6420.
Hu X, Hicks CW, He W, Wong P, Macklin WB, Trapp BD, Yan R (2006) Bace1 modulates myelination in the central and peripheral nervous system. Nat Neurosci 9:1520-1525.

Jiang L, Role LW (2008) Facilitation of cortico-amygdala synapses by nicotine: activity-dependent modulation of glutamatergic transmission. J Neurophysiol 99:1988-1999.

Laird FM, Cai H, Savonenko AV, Farah MH, He K, Melnikova T, Wen H, Chiang HC, Xu G, Koliatsos VE, Borchelt DR, Price DL, Lee HK, Wong PC (2005) BACE1, a major determinant of selective vulnerability of the brain to amyloid- $\beta$ amyloidogenesis, is essential for cognitive, emotional, and synaptic functions. J Neurosci 25:11693-11709.

Liu Q, Kawai H, Berg DK (2001) $\beta$-Amyloid peptide blocks the response of $\alpha 7$-containing nicotinic receptors on hippocampal neurons. Proc Natl Acad Sci U S A 98:4734-4739.

Luo Y, Bolon B, Damore MA, Fitzpatrick D, Liu H, Zhang J, Yan Q, Vassar R, Citron M (2003) BACE1 (beta-secretase) knockout mice do not acquire compensatory gene expression changes or develop neural lesions over time. Neurobiol Dis 14:81-88.

Nicoll RA, Schmitz D (2005) Synaptic plasticity at hippocampal mossy fibre synapses. Nat Rev Neurosci 6:863-876.

O'Connor T, Sadleir KR, Maus E, Velliquette RA, Zhao J, Cole SL, Eimer WA, Hitt B, Bembinster LA, Lammich S, Lichtenthaler SF, Hébert SS, De Strooper B, Haass C, Bennett DA, Vassar R (2008) Phosphorylation of the translation initiation factor eIF2alpha increases BACE1 levels and promotes amyloidogenesis. Neuron 60:988-1009.

Ohno M, Sametsky EA, Younkin LH, Oakley H, Younkin SG, Citron M, Vassar R, Disterhoft JF (2004) BACE1 deficiency rescues memory deficits and cholinergic dysfunction in a mouse model of Alzheimer's disease. Neuron 41:27-33.

Peng X, Katz M, Gerzanich V, Anand R, Lindstrom J (1994) Human alpha 7 acetylcholine receptor: cloning of the alpha 7 subunit from the SH-SY5Y cell line and determination of pharmacological properties of native receptors and functional alpha 7 homomers expressed in Xenopus oocytes. Mol Pharmacol 45:546-554.

Perry E, Martin-Ruiz C, Lee M, Griffiths M, Johnson M, Piggott M, Haroutunian V, Buxbaum JD, Nãsland J, Davis K, Gotti C, Clementi F, Tzartos S, Cohen O, Soreq H, Jaros E, Perry R, Ballard C, McKeith I, Court J (2000) Nicotinic receptor subtypes in human brain ageing, Alzheimer and Lewy body diseases. Eur J Pharmacol 393:215-222.

Pettit DL, Shao Z, Yakel JL (2001) $\beta$-Amyloid A-42 $_{12}$ peptide directly modulates nicotinic receptors in the rat hippocampal slice. J Neurosci 21:RC120.

Puzzo D, Privitera L, Leznik E, Fà M, Staniszewski A, Palmeri A, Arancio O (2008) Picomolar amyloid- $\beta$ positively modulates synaptic plasticity and memory in hippocampus. J Neurosci 28:14537-14545.

Radcliffe KA, Fisher JL, Gray R, Dani JA (1999) Nicotinic modulation of glutamate and GABA synaptic transmission of hippocampal neurons. Ann N Y Acad Sci 868:591-610.

Savonenko AV, Melnikova T, Laird FM, Stewart KA, Price DL, Wong PC (2008) Alteration of BACE1-dependent NRG1/ErbB4 signaling and schizophrenia-like phenotypes in BACE1-null mice. Proc Natl Acad Sci U S A 105:5585-5590.

Séguéla P, Wadiche J, Dineley-Miller K, Dani JA, Patrick JW (1993) Molecular cloning, functional properties, and distribution of rat brain $\alpha_{7}$ : a nicotinic cation channel highly permeable to calcium. J Neurosci 13:596-604.

Sharma G, Vijayaraghavan S (2003) Modulation of presynaptic store calcium induces release of glutamate and postsynaptic firing. Neuron 38:929-939.

Sharma G, Grybko M, Vijayaraghavan S (2008) Action potential-independent and nicotinic receptor-mediated concerted release of multiple quanta at hippocampal CA3-mossy fiber synapses. J Neurosci 28:25632575.

Shimizu H, Fukaya M, Yamasaki M, Watanabe M, Manabe T, Kamiya H (2008) Use-dependent amplification of presynaptic Ca2 + signaling by axonal ryanodine receptors at the hippocampal mossy fiber synapse. Proc Natl Acad Sci U S A 105:11998-12003.

Vassar R, Kovacs DM, Yan R, Wong PC (2009) The $\beta$-secretase enzyme BACE in health and Alzheimer's disease: regulation, cell biology, function, and therapeutic potential. J Neurosci 29:12787-12794. 
Vijayaraghavan S, Pugh PC, Zhang ZW, Rathouz MM, Berg DK (1992) Nicotinic receptors that bind alpha-bungarotoxin on neurons raise intracellular free $\mathrm{Ca} 2+$. Neuron 8:353-362.

Walsh DM, Selkoe DJ (2007) A beta oligomers-a decade of discovery. J Neurochem 101:1172-1184.

Wang H, Song L, Laird F, Wong PC, Lee HK (2008) BACE1 knock-outs display deficits in activity-dependent potentiation of synaptic transmission at mossy fiber to CA3 synapses in the hippocampus. J Neurosci 28:8677-8681.

Wang HY, Lee DH, Davis CB, Shank RP (2000a) Amyloid peptide Abeta(1-42) binds selectively and with picomolar affinity to alpha7 nicotinic acetylcholine receptors. J Neurochem 75:1155-1161.
Wang HY, Lee DH, D’Andrea MR, Peterson PA, Shank RP, Reitz AB (2000b) $\beta$-Amyloid A $_{1-42}$ binds to $\alpha 7$ nicotinic acetylcholine receptor with high affinity. Implications for Alzheimer's disease pathology. J Biol Chem 275:5626-5632.

Willem M, Garratt AN, Novak B, Citron M, Kaufmann S, Rittger A, DeStrooper B, Saftig P, Birchmeier C, Haass C (2006) Control of peripheral nerve myelination by the beta-secretase BACE1. Science 314:664-666.

Zhong C, Du C, Hancock M, Mertz M, Talmage DA, Role LW (2008) Presynaptic type III neuregulin 1 is required for sustained enhancement of hippocampal transmission by nicotine and for axonal targeting of $\alpha 7$ nicotinic acetylcholine receptors. J Neurosci 28:9111-9116. 